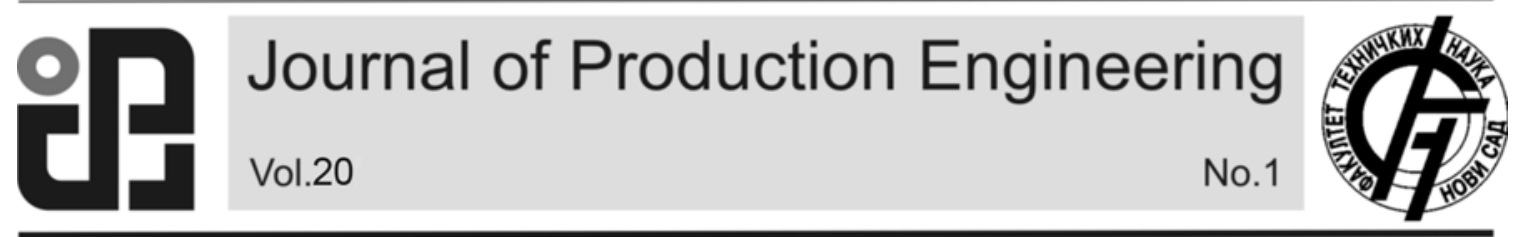

JPE (2017) Vol.20 (1)

Kovač, P., Rodić, D., Gostimirović, M., Savković, B., Ješić. D.

Original Scientific Paper

\title{
ADAPTIVE NEURO-FUZZY MODELING OF THERMAL VOLTAGE PARAMETERS FOR TOOL LIFE ASSESSMENT IN FACE MILLING
}

Received: 23 January 2017 / Accepted: 08 May 2017

\begin{abstract}
The focus of this paper is to develop a reliable procedure to predict tool life during face milling process. This procedure involves a combination of Method of Least Squares and Neuro Fuzzy system. The factorial designs combined with the ANFIS techniques were applied to perform the prediction of thermal voltage. A least-squares linear regression is applied to perform the prediction of tool life from thermal-voltage signals. In this contribution we also discussed the construction of an ANFIS system that tends to provide a linguistic model for the estimation of thermal voltage obtained with different membership functions. This research focuses on developing ANFIS models using triangular and Gaussian membership functions. The work shows that the membership functions have the dominant effect among the on the accuracy model. The results indicate that the training of ANFIS with the Gaussian membership function obtains a higher accuracy rate in the prediction of thermal voltage, respectively tool life.
\end{abstract}

Key words: ANFIS, thermal voltage, tool life, face milling.

Modelovanje termo-napona pomoću neuro-fazi sistema pri proceni postojanosti alata kod čeonog glodanja. Cilj ovog rada je da se razvije pouzdan postupak za procenu postojanosti alata tokom procesa čeonog glodanja. Ovaj postupak obuhvata kombinaciju metode najmanjih kvadrata i neuro-fazi sistema. Za predvidjanje termonapona korišćen je ANFIS postupak na osnovu faktorijalnog dizajna eksperimenta. Razvijena je regresiona jednačina koja se dobija metodom najmanjih kvadrata i služi za procenu postojanosti alata na osnovu vrednosti termo-napona. U ovom radu se takođe diskutuje o načinu formiranja ANFIS modela upotrebom različitih funkcija pripadnosti pri određivanju termo-napona. Korišćenjem trougaonih i Gausovih funkcija pripadnosti razvijeni su ANFIS modeli. Pokazalo se da izbor tipa funkcije pripadnosti utiče na tačnost modela. Rezultati istraživanja su potvrdili da obuka ANFIS modela sa Gausovim funkcijama pripadnosti daje tačnije predviđanje termo-napona, odnosno postojanosti alata.

Ključne reči: ANFIS, termo-napon, postojanost alata, čeono glodanje.

\section{INTRODUCTION}

Tool life in the metal cutting process are very important factors affecting production optimization. The importance of tool life prediction for the machining processes has been well recognized in the machining research community primarily due to its constraints on the productivity [1]. Intelligent models of face milling processes provide the ability to predict stable cutting condition and increases tool life for a large combination of process [2].

The application of the Adaptive Neural Fuzzy Inference System (ANFIS) for the modeling purpose in various different areas including machining is used a widely by researchers [3, 4]. Several intelligent models for predicting as well as classifying tool life in machining operations have been developed $[5,6]$. Zuper et al. developed a reliable method to predict flank wear during end milling process. They applied a neural-fuzzy system to perform the prediction of flank wear from cutting force signals [7]. A fuzzy logic based in-process tool-wear monitoring system is developed by Chen and Susanto. In this system the fuzzy membership function and rule bank were based on observations during cutting experiments using artificial tool-wear inserts in face milling operations [8]. Sokolowski introduced a new fuzzy rule acquisition method for tool wear estimation. It uses radial basis networks to find the optimal combination of rules to compose a fuzzy reasoning mechanism and options related to the membership functions [9]. ANFIS is a theory used to describe the relationship between system inputs and outputs. It is widely used to develop rule based expert systems in modeling of complex processes that difficult be modeled analytically under various assumptions [10]. Cutting forces and cutting conditions including speed, feed and depth of cut have been usually employed as input units in these prediction models. But very few researchers used the ANFIS to predict the tool life in face milling by thermal-voltage. Further, the impact of different membership functions which are utilized in the ANFIS model on the correct rate of prediction of tool life by thermal-voltage was not investigated yet. The selection of acceptable fuzzy membership function is generally a subjective decision, it is by trial and error and very time-consuming.

This paper focuses on developing ANFIS models using Triangular and Gaussian membership functions. The values of thermal voltage predicted by these models are then compared. In this research we attempt to solve this situation by using the adaptive neuro-fuzzy inference system (ANFIS) to predict the thermal voltage of the tool in face milling process. After obtained ANFIS models, tool life is predicted by the method of least squares. 


\section{EXPERIMENTAL SETUP}

In order to develop the tool life prediction model, experimental results were used. Experimental investigation was conducted on a vertical milling machine without cooling lubrication fluid. A singletooth face, milling cutter of $125 \mathrm{~mm}$ diameter, with a carbide P 25 insert SPAN 1203 ER was used. The working material was a block of 100x120x600 mm of steel AISI 1060 and was fixed on milling machine table. The experiment was carried out for different combinations of cutting speed $(\mathrm{v})[\mathrm{m} / \mathrm{s}]$, feed per tooth (f) $[\mathrm{mm} / \mathrm{t}]$ and cutting depth (a) $[\mathrm{mm}]$ according to the planning of experiment, Table 1. Tool-work thermocouple thermal voltage was measured as shown in Fig. 1. To avoid thermal voltage leak, the workpiece was insulated from the machine tool on all contact surfaces. The carbide insert was insulated from the tool holder as well, to avoid thermal voltage noise. The cold junction on the tool was moved away from the cutting zone by adding carbide insert parts of the same kind of carbide used to avoid parasitic thermal voltage. This system is shown with detail enlarged in Fig.1. The cold junction temperature, at the end of the milling cutter, was monitored by artificial thermocouple to avoid scattering.

\begin{tabular}{|c|c|c|c|c|c|}
\hline No. & $\begin{array}{c}\text { Cutting } \\
\text { speed } \\
(\mathbf{m} / \mathbf{s})\end{array}$ & $\begin{array}{c}\text { Feed } \\
\mathbf{( m m / ~} \\
\text { tooth) }\end{array}$ & $\begin{array}{c}\text { Depth } \\
\text { of cut } \\
\text { (mm) }\end{array}$ & $\begin{array}{c}\text { Thermal } \\
\text { Voltage } \\
\text { (mV) }\end{array}$ & $\begin{array}{c}\text { Tool } \\
\text { Life } \\
\text { (min) }\end{array}$ \\
\hline 1. & 2.32 & 0.178 & 1 & 12.1 & 59 \\
\hline 2. & 3.67 & 0.178 & 1 & 13.4 & 20 \\
\hline 3. & 2.32 & 0.28 & 1 & 12.7 & 35 \\
\hline 4. & 3.67 & 0.28 & 1 & 14.2 & 11 \\
\hline 5. & 2.32 & 0.178 & 2.25 & 12.7 & 36 \\
\hline 6. & 3.67 & 0.178 & 2.25 & 14 & 13 \\
\hline 7. & 2.32 & 0.28 & 2.25 & 13.4 & 20 \\
\hline 8. & 3.67 & 0.28 & 2.25 & 14.8 & 7 \\
\hline 9. & 2.95 & 0.223 & 1.5 & 13.4 & 18 \\
\hline 10. & 2.95 & 0.223 & 1.5 & 13.4 & 22 \\
\hline 11. & 2.95 & 0.223 & 1.5 & 13.6 & 17 \\
\hline 12. & 2.95 & 0.223 & 1.5 & 13.7 & 18 \\
\hline 13. & 1.83 & 0.223 & 1.5 & 12.1 & 52 \\
\hline 14. & 4.65 & 0.223 & 1.5 & 14.9 & 7 \\
\hline 15. & 2.95 & 0.142 & 1.5 & 12.6 & 38 \\
\hline 16. & 2.95 & 0.351 & 1.5 & 14.1 & 12 \\
\hline 17. & 2.95 & 0.223 & 0.67 & 12.8 & 30 \\
\hline 18. & 2.95 & 0.223 & 3.37 & 15 & 6 \\
\hline 19. & 1.83 & 0.223 & 1.5 & 12.2 & 50 \\
\hline 20. & 4.65 & 0.223 & 1.5 & 15 & 6 \\
\hline 21. & 2.95 & 0.142 & 1.5 & 12.5 & 41 \\
\hline 22. & 2.95 & 0.351 & 1.5 & 14 & 13 \\
\hline 23. & 2.95 & 0.223 & 0.67 & 12.9 & 27 \\
\hline 24. & 2.95 & 0.223 & 3.37 & 14.9 & 6 \\
\hline & & & & \\
\hline
\end{tabular}

Table 1. Experimental data

The measurement of thermal-voltage was performed by a natural thermocople tool-workpiece. From turning spindle of milling machine signal transmitting is made by slip rings. Reading of thermalvoltage was done digitally on the "digital thermometer" - TR 2112 instrument equipped. The factorial designs combined with the ANFIS techniques were applied. ANFIS modeling process starts by obtaining a data set (input-output data) and dividing it into training and checking data sets.

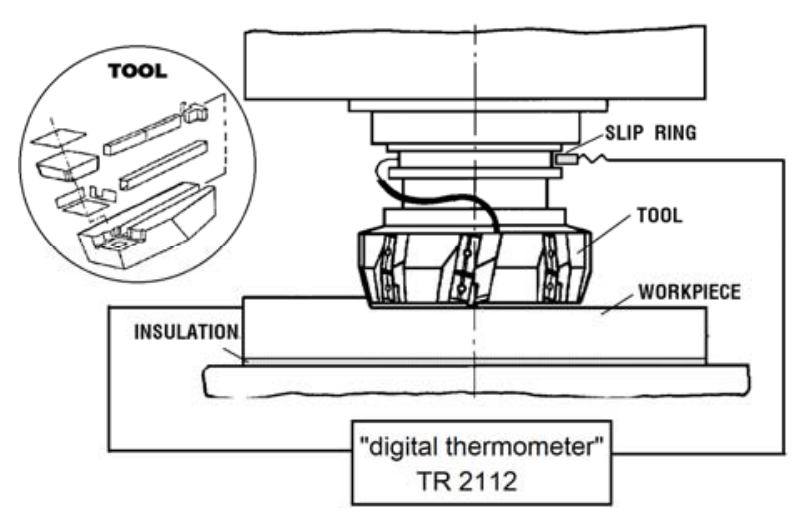

Fig. 1. The tool-workpiece thermocouple experimental setup

\section{ANFIS MODELING}

Figures Adaptive neuro-fuzzy inference system (ANFIS) is an architecture which is functionally equivalent to a Sugeno type fuzzy rule base. Both artificial neural network (ANN) and fuzzy logic (FL) are used in ANFIS architecture, figure 2 and 3.

ANFIS normally has 5 layers of neurons of which neurons in the same layer are of the same function family. Each node generates the membership grades of a linguistic label. In this paper an example of a membership functions are triangular and Gaussian membership functions:

Gaussian $f(x, \sigma, c)=e^{\frac{-\left(I_{e}-c\right)^{2}}{2 \sigma^{2}}}$
Traingular $f(x, a, b, c)=\max \left\{\min \left(\frac{x-a}{b-2}, \frac{c-x}{c-b}\right), 0\right\}$

where $(\mathrm{x}, \sigma, \mathrm{c})$ and $(\mathrm{x}, \mathrm{a}, \mathrm{b}, \mathrm{c})$ are the parameter set. As the values of the parameters change, the shape of the membership functions varies. Parameters in that layer are called premise parameters.

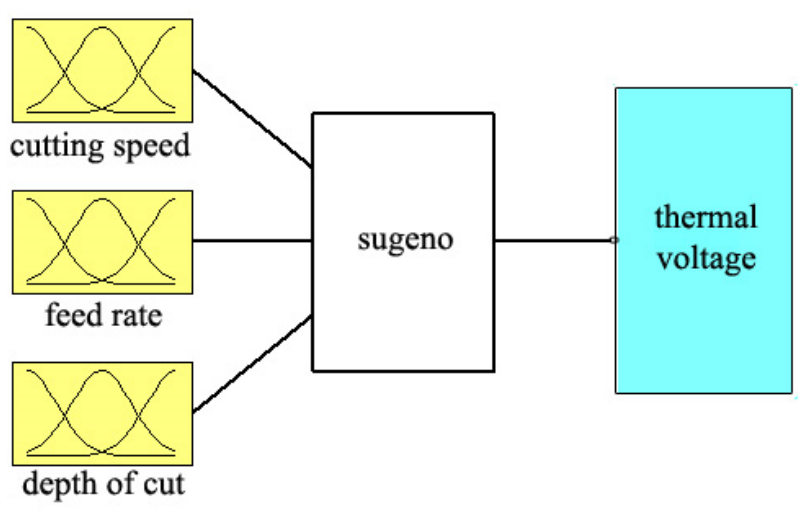

Fig. 2. Fuzzy inference system of ANFIS

In layer two, each node calculates the firing strength of each rule using the min or prod operator. In general, any other fuzzy AND operation can be used. The layer three enables to calculate nodes the ratios of the rule's 
firing strength to the sum of all the rules firing strength. The result is a normalized firing strength. In layer four, the nodes compute a parameter function on the layer 3 output. Parameters in this layer are called consequent parameters. Finally in the layer five, normally a single node that aggregates the overall output as the summation of all incoming signals.

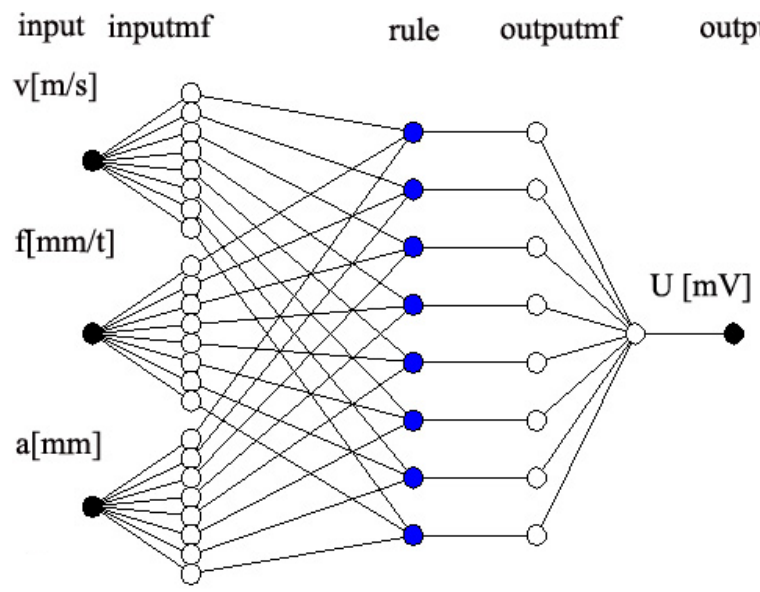

Fig. 3. Five-layer neural network of ANFIS

In our case ANFIS is a five-layer neural network that simulates the working principle of a fuzzy inference system. The ANFIS model generated from the membership functions and rules were data-driven by the process data for each mechanical property.

In this paper, a straightforward approach for designing an ANFIS model is presented to evaluate the effect of membership function in ANFIS model, and presents the performance comparison of ANFIS model with two different types of membership function. Though there are many numbers of membership functions available like triangular, trapezoidal, Gaussian, etc.

The modeling of the thermo voltage in this paper are using the triangular and the Gaussian types of membership functions as described by Klir and Folger [11]. Each set of process data collected from the extrusions consisted of 24 data points from which 20 and 4 were selected randomly for training and testing, respectively.
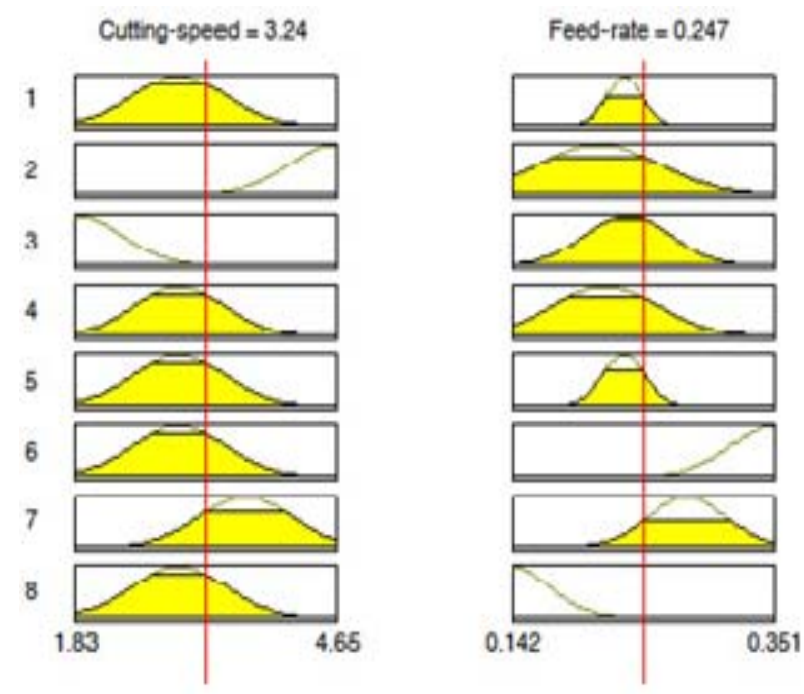

This paper presents a method for reduction in the fuzzy inference system, where the ANFIS model based on subtractive clustering is designed to predict for thermal voltage. Subtractive clustering is an extension of the mountain clustering method and which is more efficient at finding cluster centers. The subtractive clustering method assumes that each data point is a potential cluster center and, without prior knowledge of the default number of centers, it calculates the likelihood of a data point being defined as a cluster center according to the density of the surrounding data points [12]. The objective of using this approach is to design a ANFIS model with less number of rules leading to a smaller amount of computational time.

For example, in a three-input ANFIS model with 8 membership functions for each input, the possible rules are $8^{3}=512$, and if the number of inputs are increased, this number will quickly increase. To overcome this problem, the user may want to put constraints on the type membership functions or limit the rules. In this case, rather than 512 rules (conventional ANFIS with Triangular MF) adopted 8 (clustering based ANFIS with Gaussian MF), which are shown in figure 4.

Throughout the initial experiment, the parameter values used in the proposed ANFIS were set as follows. Parameters for clustering is: range of influence (0.5), squash factor $(1.25)$, accept ratio $(0.5)$ and reject ratio (0.15). The models were developed and implemented using 500 epochs. The input and output data sets contained three inputs [cutting speed, feed rate and depth of cut] and one output (thermal voltage).

The linguistic nodes in layers one and five represent the input and output linguistic variables, respectively. Nodes in layers two are term nodes acting as membership functions for input variables. Number of membership for each input parameters is eight. Each neuron in the third layer represents one fuzzy rule, with input connections representing preconditions of the rule and the output connection representing consequences of the rules. Initially, all these layers are fully connected, representing all possible rules. The hybrid batch learning rules are used in the training. Due to limitation of space, the results of conventional ANFIS are not included here.
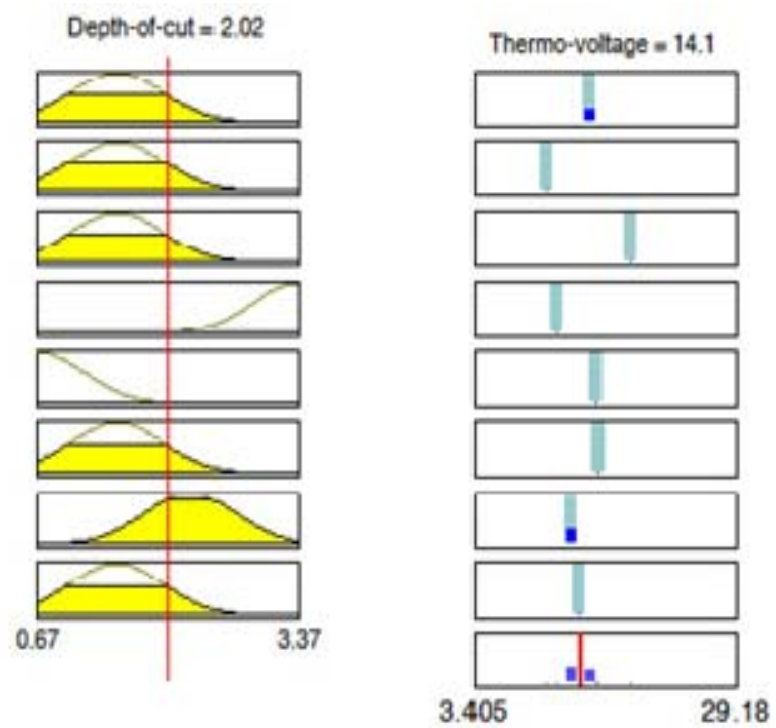

Fig. 4. Rule base (Gauss MF) of ANFIS model for predicting thermal-voltage 


\section{METHOD OF LEAST SQUARES FOR DETERMINING TOOL LIFE}

The Method of Least Squares is a procedure to determine the best fit line to data. Least-squares linear regression is a statistical technique that may be used to estimate the tool life at the given level of thermal voltage based on experimental data, table 1. After experimental data processing, convenient mathematical models are evaluated by the coefficient of correlation value and on the basis of the magnitude of exponents in the exponential relationships and adequate linear regression model was obtained:

$$
T=1.5682919 \times 10^{13} \times U^{-10.56296}
$$

The scatterplot on figure 4. shows that the relationship between tool life and thermal voltage scores is linear.

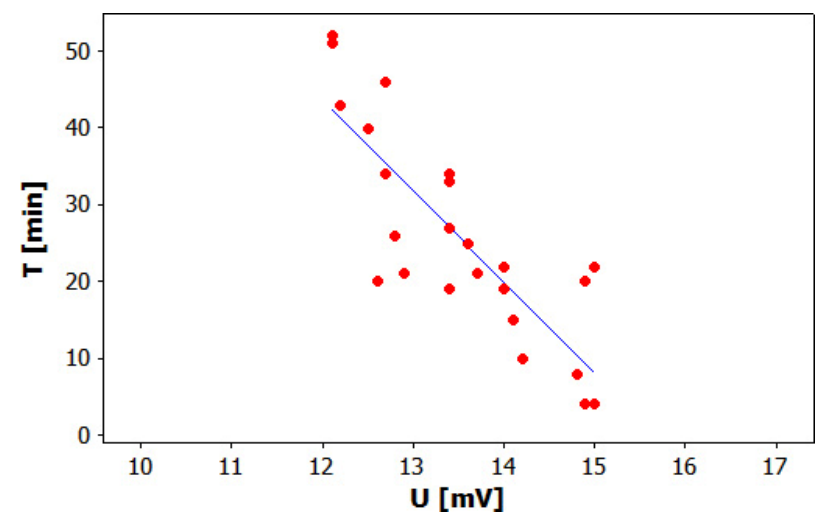

Fig. 5. The dependence on tool life of thermal voltage

In accordance with the presented we can generally conclude that, for proposed model, corresponding coefficient of correlation are sufficiently high $(\mathrm{R}=0.889)$, and the model can be used for predicting the tool life in machining of carbon steel.

\section{RESULTS}

In this research ANFIS system is used to predict the thermal-voltage in a face milling process. Based on the predicting thermal voltage using the least squares method can be calculated tool life. Because of thermal voltage signals have more information than other emission signals, the relationship between the thermal voltage and tool life was examined. The thermalvoltage value predicted by ANFIS are compared with the measurement values derived from the 24 data sets in order to determine the error of ANFIS. A comparison between the clustering based ANFIS with Gaussian MF and conventional ANFIS with Triangular MF is presented. The results indicate that the training of ANFIS with the Gaussian membership function obtains a higher accuracy rate in the prediction of thermal voltage. The experimental results indicate that the proposed ANFIS model has a high accuracy for estimating thermal-voltage with small computational time.
Figure 6-8 shows the effect of cutting parameters on the thermal voltage based on ANFIS model. According to Fig. 6, 7 and 8 cutting speed, feed rate and depth of cut had considerable effect on thermal voltage, while an increase in both cutting speed and/or feed rate, when depth of cut held constant, led to an increase in thermal voltage, but feed rate had a minor effect on thermal voltage. The ANFIS model show that the maximum thermal voltage is at the highest levels of cutting speed and depth of cut, figure 7 .

\begin{tabular}{|c|c|c|c|c|c|c|}
\hline \multirow[t]{2}{*}{ No. } & \multirow{2}{*}{$\begin{array}{c}\text { Cutting } \\
\text { speed } \\
(\mathrm{m} / \mathrm{s})\end{array}$} & \multirow{2}{*}{$\begin{array}{c}\text { Feed } \\
(\mathrm{mm} / \mathrm{t})\end{array}$} & \multirow{2}{*}{$\begin{array}{l}\text { Depth } \\
\text { of cut } \\
(\mathrm{mm})\end{array}$} & \multicolumn{3}{|c|}{ Thermal voltage $(\mathrm{mV})$} \\
\hline & & & & Exp. & $\begin{array}{c}\text { Gauss. } \\
\text { MF }\end{array}$ & $\begin{array}{c}\text { Trian. } \\
\text { MF }\end{array}$ \\
\hline 1. & 2.32 & 0.178 & 1 & 12.1 & 11.2 & 10.1 \\
\hline 2. & 2.32 & 0.28 & 2.25 & 13.4 & 13.8 & 14.2 \\
\hline 3. & 2.95 & 0.142 & 1.5 & 12.6 & 12.5 & 13.6 \\
\hline 4. & 2.95 & 0.351 & 1.5 & 14 & 14.1 & 14.9 \\
\hline \multicolumn{5}{|c|}{ Average error [\%]: } & 3.11 & 9.7 \\
\hline
\end{tabular}

Table 2. Predicted value of thermal voltage for gaussian and triangular membership functions

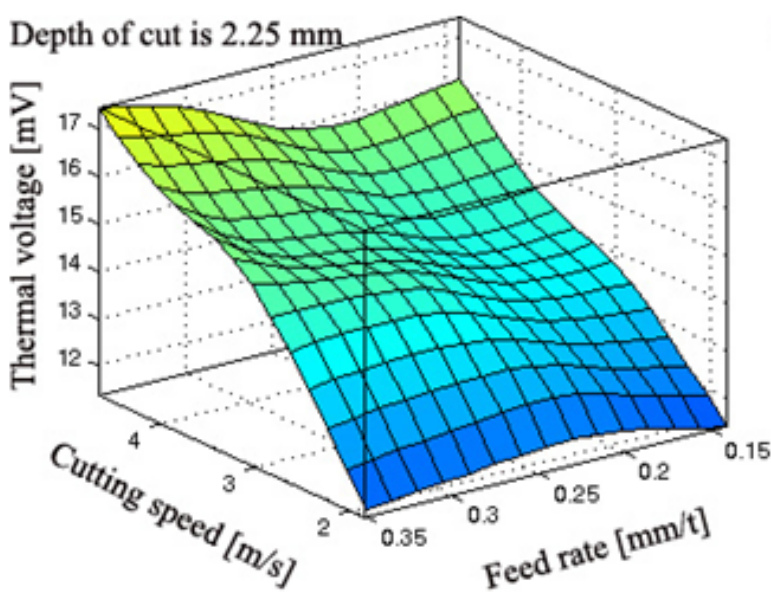

Fig 6. Effect of cutting speed and feed rate on thermal voltage where is depth of cut constant

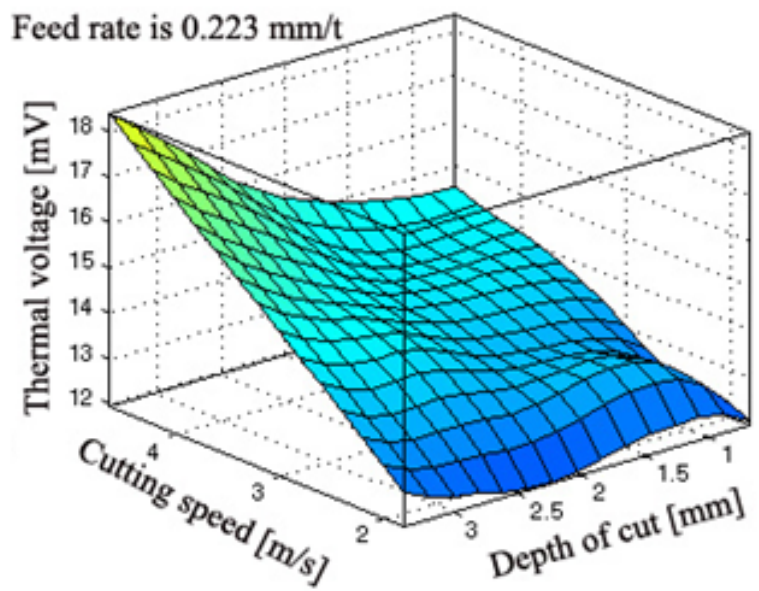

Fig. 7. Effect of cutting speed and depth of cut on thermal voltage where is feed rate constant 


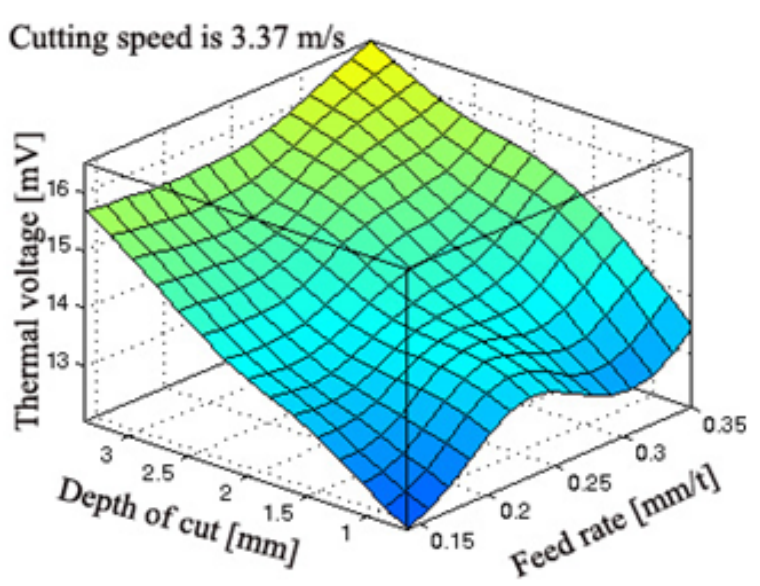

Fig. 8. Effect of depth of cut and feed rate on thermal voltage where is cutting speed constant

\section{CONCLUSION}

This study concludes that the cutting speed and feed rate are the most significant parameters affecting the thermal voltage, respectively tool life. The depth of cut has minor effect on the thermal voltage. ANFIS was successfully used to develop an empirical model for modeling the relation between the predictor variables $(\mathrm{v}$, $\mathrm{f}$ and a) and the performance parameter thermal voltage. ANFIS model with Gaussian membership functions is accurate and can be used to predict thermal voltage in face milling operation with average percentage errors $3.11 \%$.

\section{REFERENCES}

[1] Kovac, P., M. Gostimirovic, and D. Milikic, Prediction of the Tool Life Function Based on the Tool-Work Thermocouple Temperature During Milling. International Journal For Manufacturing Science And Production.Vol. 2(4): pp. 199-206, 1999.

[2] Kovac, P., et al., Multi-output fuzzy inference system for modeling cutting temperature and tool life in face milling. Journal of Mechanical Science and Technology.Vol. 28(10): pp. 4247-4256, 2014.

[3] Dinakaran, D., S. Sampathkumar, and N. Sivashanmugam, An experimental investigation on monitoring of crater wear in turning using ultrasonic technique. International Journal of Machine Tools and Manufacture.Vol. 49(15): pp. 1234-1237, 2009.

[4] Maher, I., et al., Investigation of the effect of machining parameters on the surface quality of machined brass (60/40) in CNC end millingANFIS modeling. The International Journal of Advanced Manufacturing Technology.Vol. 74(14): pp. 531-537, 2014.
[5] Massol, O., et al. An exTS based neuro-fuzzy algorithm for prognostics and tool condition monitoring. in Control Automation Robotics \& Vision (ICARCV), 2010 11th International Conference on. 2010. IEEE.

[6] Rizal, M., et al., Online tool wear prediction system in the turning process using an adaptive neuro-fuzzy inference system. Applied Soft Computing.Vol. 13(4): pp. 1960-1968, 2013.

[7] Uros, Z., C. Franc, and K. Edi, Adaptive network based inference system for estimation of flank wear in end-milling. Journal of Materials Processing Technology.Vol. 209(3): pp. 15041511, 2009.

[8] Chen, J. and V. Susanto, Fuzzy logic based inprocess tool-wear monitoring system in face milling operations. The International Journal of Advanced Manufacturing Technology.Vol. 21(3): pp. 186-192, 2003.

[9] Sokołowski, A., On some aspects of fuzzy logic application in machine monitoring and diagnostics. Engineering Applications of Artificial Intelligence.Vol. 17(4): pp. 429-437, 2004.

[10] Gill, S.S., et al., Adaptive neuro-fuzzy inference system modeling of cryogenically treated AISI M2 HSS turning tool for estimation of flank wear. Expert Systems with Applications.Vol. 39(4): pp. 4171-4180, 2012.

[11] Klir, G.J. and T.A. Folger, Fuzzy sets, uncertainty, and information. 1988.

[12] Chen, M.-Y., A hybrid ANFIS model for business failure prediction utilizing particle swarm optimization and subtractive clustering. Information Sciences.Vol. 220: pp. 180-195, 2013.

\section{ACKNOWLEDGMENT}

This paper is the result of the research within the project TR 35015 financed by the Ministry of Science and Technological Development of the Republic of Serbia.

Authors: ${ }^{1}$ Professor Pavel Kovač PhD, ${ }^{1}$ Research Associate Dragan Rodé MSc, ${ }^{1}$ Professor Marin Gostimirović PhD, ${ }^{1}$ Assist. Professor Borislav Savković PhD, ${ }^{2}$ Professor Dušan Ješić PhD.

${ }^{1}$ University of Novi Sad, Faculty of Technical Sciences, Institute for Production Engineering, Trg Dositeja Obradovica 6, 21000 Novi Sad, Serbia, Phone.: +381 21 450-366, Fax: +381 21 454-495.

${ }^{2}$ MTM Academia, Novi Sad, Serbia.

E-mail: pkovac@uns.ac.rs rodicdr@uns.ac.rs maring@uns.ac.rs savkovic@uns.ac.rs dusanjesic@hotmail.com 